\title{
22. THE CRETACEOUS/TERTIARY BOUNDARY EVENT IN THE NORTH ATLANTIC
}

\author{
Hans R. Thierstein, Scripps Institution of Oceanography, University of California, San Diego, La Jolla, California \\ and \\ Hisatake Okada, ${ }^{1}$ Department of Geology, Faculty of Science, Yamagata University, Yamagata, Japan
}

\begin{abstract}
Paleomagnetic evidence suggests that the Cretaceous/Tertiary transition at DSDP Site 384 is continuous. Quantitative taxonomic analysis of the nannolith assemblages indicates that all taxa within the Cretaceous assemblage became extinct simultaneously. The evolutionary sequence of the Tertiary assemblages at Site 384 is characterized by an initial dominance of Thoracosphaera, Zygodiscus sigmoides and Markalius astroporus, a following Braarudosphaera bloom, and a subsequent gradual increase of Cruciplacolithus primus and C. tenuis. The preserved nannolith record can be explained by benthic mixing with an incompletely homogenized mixed layer of $21 \mathrm{~cm}$ in thickness. The carbonate record in the deep North Atlantic documents a major excursion ( $>2$ $\mathrm{km}$ ) of the carbonate compensation surface to abyssal paleodepths from middle Maestrichtian to middle Danian time. Comparison with the scanty sedimentary evidence from the deep Pacific and Indian oceans suggests a late Mesozoic deep water fractionation between the Pacific and the Atlantic oceans with deep circulation reversals just prior and subsequent to the evolutionary Cretaceous/Tertiary boundary extinction event.
\end{abstract}

\section{THE MAESTRICHTIAN-DANIAN TRANSITION AT SITE 384}

The Cretaceous-Tertiary boundary was penetrated in Section 3 of Core 13 with abundant and well-preserved nannoliths above and below. This provided a unique opportunity to study in detail the stratigraphy of the nannoplankton extinctions at the end of the Mesozoic. Bramlette and Martini (1964), Bramlette (1965), and Worsley $(1971,1974)$ have drawn attention to these extinctions as major evolutionary events. Closely spaced samples, using toothpicks, were taken across the boundary on board ship. Their exact location with regard to lithology and color was recorded from Samples $384-13-3,20 \mathrm{~cm}$ to $384-13-3,70 \mathrm{~cm}$, i.e., from 167.80 to 168.30 meters sub-bottom depth and is shown in Figure 1.

\section{Lithology}

The entire Section 3 of Core 13 consists of pale yellow to white nannolith chalk and is described and illustrated in detail in the site report (Chapter 4). Changes in color and texture are identified in Figure 1. The small domains of darker sediment between 167.98 and 168.12 meters sub-bottom depth show the same color as the

\footnotetext{
${ }^{1}$ Formerly at Lamont-Doherty Geological Observatory, Palisades, New York.
}

matrix above 167.92 meters, but lack the small dark brown patches observed above that level. The darker domains between 167.98 and 168.12 meters are surrounded by a light matrix which is similar to the homogeneous chalk below 168.20 meters. At this depth a horizontal burrow suggests that the sediment is in its original position and has not been disturbed by postdepositional slumping or by the drilling process. A color change from white (below) to pale yellow (above) is observed in the matrix at 167.93 meters depth. Conspicuous oval burrows with a ring of white sediment are embedded in the pale yellow matrix between 167.89 and 167.92 meters. A few patches of white ooze similar to the matrix below 167.93 meters, occur in the darker pale yellow matrix between 167.65 and 167.71 meters. The lithologic record suggests either drilling disturbance or slumping shortly after deposition as explanation for the presence of the darker domains below the color change of the matrix. The white burrow fillings and patches above the color change suggest reworking of pale matrix from below. If these color correlations are correct, they should be reflected in the similarities of the nannolith assemblages they contain.

\section{Nannofossils}

The stratigraphic distribution of nannoliths based on visual examination of several thousand specimens in each sample is shown in Table 1 . The lowermost occurrences of a number of taxa, although in very low abun- 


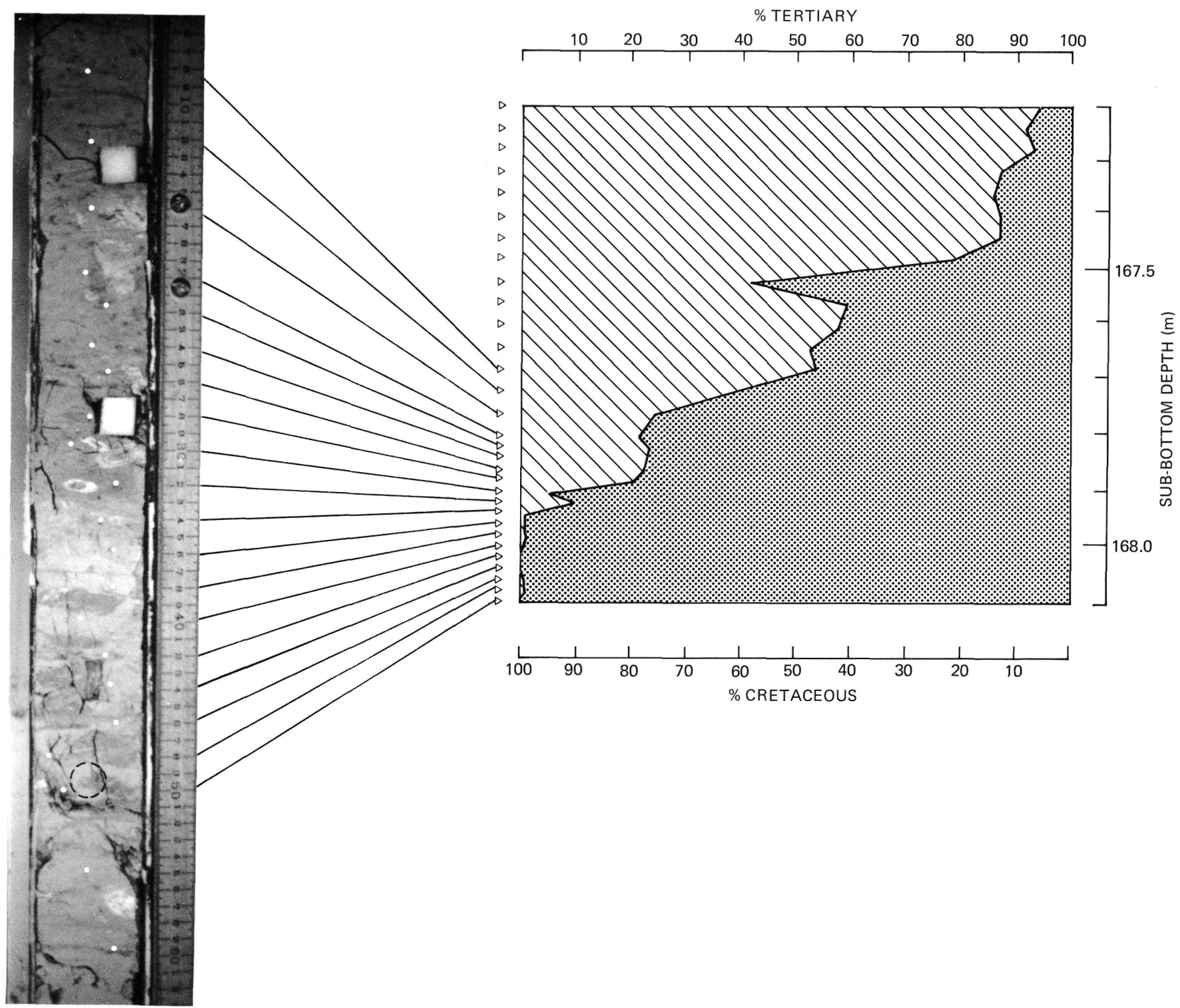

Figure 1. Lithology and nannolith proportions at the Cretaceous/Tertiary boundary in DSDP Site 384, Core 13, Section 3 (NW Atlantic). Taxa considered Cretaceous or Tertiary are distinguished in Figure 2 by assignment of asterisks to taxa considered as Tertiary. For criteria used for separation, see discussion in text. A recently received sample from the darker domain at 13-3, $50 \mathrm{~cm}$ (168.10 m sub-bottom depth) outlined as dashed circle contained 92.7 per cent Cretaceous and 7.3 per cent Tertiary taxa (see text for discussion).

dances, are observed in the upper part of the upper Maestrichtian. Starting at 168.20 meters sub-bottom depth they include Thoracosphaera spp., Markalius astroporus, Crepidolithus spp., Chiasmolithus danicus, Zygodiscus sigmoides, and Braarudosphaera spp. All taxa (except $C$. danicus) have been reported previously from Maestrichtian sediments by Bramlette and Martini (1964) and Perch-Nielsen (1969, 1973). Only three taxa seem to disappear in the upper Maestrichtian interval at Site 384: Zygodiscus diplogrammus (s. ampl.), Broinsonia enormis, and Nephrolithus frequens. The scarce and intermittent occurrences recorded for these species in the upper Maestrichtian, and the presence of $N$. frequens (reworked?) above the color change at 167.93 meters (Table 1) illustrate the limited significance of these "extinctions." The interval immediately above the color change contains the first occurrences of Biantholithus sparsus, Cruciplacolithus primus, Cruciplacolithus tenuis, and Goniolithus fluckigeri at 167.93 meters, Neochiastozygus concinnus at 167.44 meters, Coccolithus pelagicus (s. ampl.) and Ericsonia subpertusa at 166.70 meters, and Chiasmolithus danicus at 163.00 meters sub-bottom depth.

The presence of $C$. tenuis at the very base of the Danian is in disagreement with some proposed Paleocene nannofossil zonations (Hay and Mohler, 1967; Perch-Nielsen, 1969; Martini, 1971) in which the lowermost Danian nannolith zone (M. astroporus Zone) is defined as the interval between the extinction of the 
TABLE 1

Stratigraphic Distribution of Nannoliths Across the Cretaceous/Tertiary Boundary at DSDP Site 384

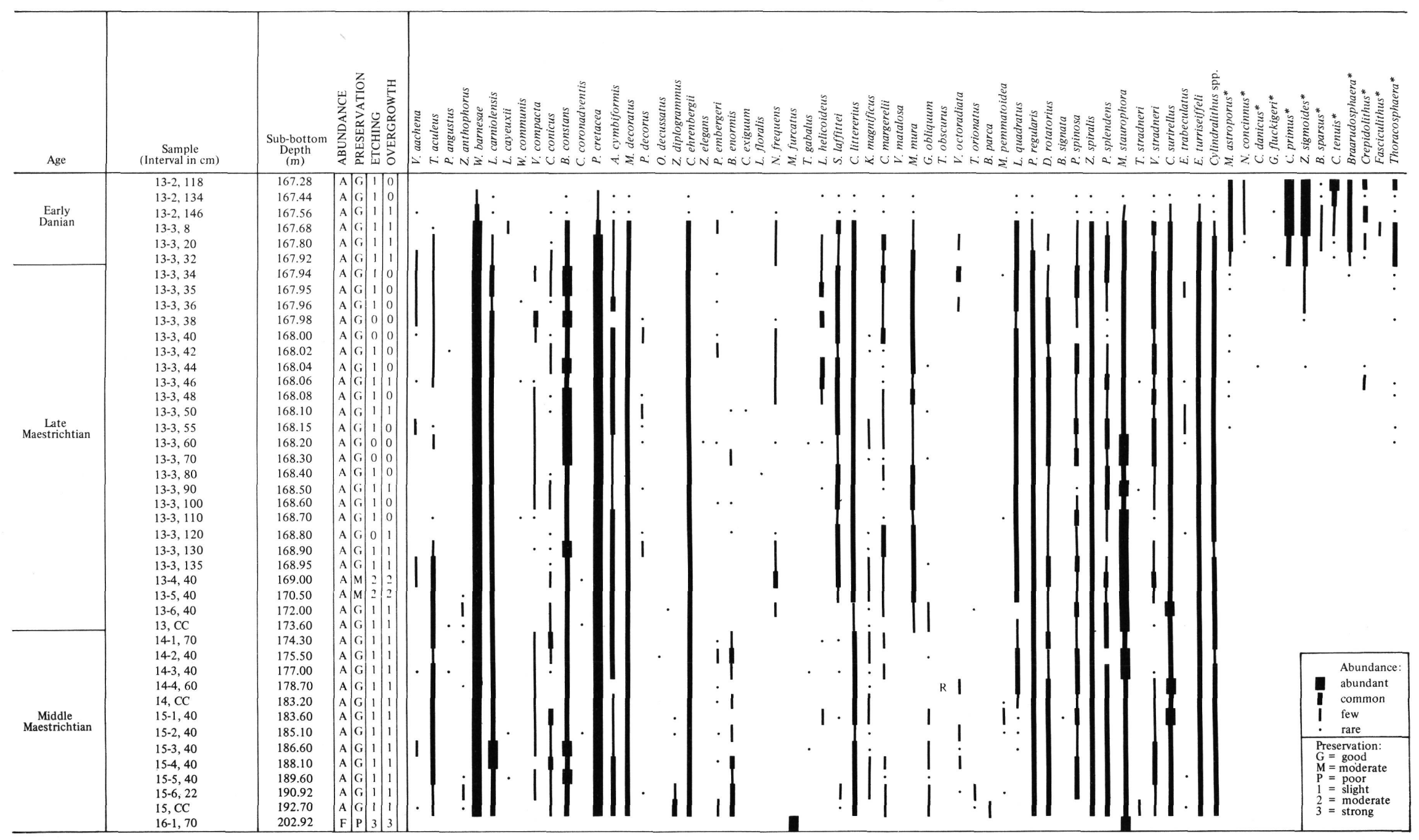

Note: Taxa considered Tertiary in this study are distinguished by an asterisk. 
Cretaceous taxa and the lowermost occurrence of the $C$. tenuis. Does this indicate that the earliest Danian is missing at Site 384? Nannolith assemblages characteristic of Hay and Mohler's (1967) Markalius astroporus Zone (syn. M. inversus Zone of Martini, 1971) have been reported from Pont Labau, France (Hay and Mohler, 1967), Dania, Kjölby Gaard and other localities in Denmark (Bramlette and Martini, 1964; Perch-Nielsen, 1969), Lattengebirge (Martini, 1971), and Braggs in Alabama (Worsley, 1974). The Danian assemblages from Pont Labau, Denmark, and Braggs are poorly preserved, with evidence of strong dissolution and subsequent recrystallization. Since $C$. tenuis and particularly its smaller evolutionary ancestor $C$. primus are of very fragile construction, slight dissolution will obliterate the species from the assemblage.

The more recently published records of the Markalius astroporus Zone (NP 1) from the deep sea confirm the possibility that the absence of $C$. tenuis in some sections may be a preservational feature. The possible maximum thicknesses available to accommodate a non-encountered NP 1 interval at various deep-sea drilling sites are listed in Table 2. A strong correlation between dissolution of nannofossils and thickness of Zone NP 1 is evident. Thus excellent preservation of the earliest Danian assemblages, rather than a hiatus appear to be the reason for the "absence" of Zone NP 1 at Site 384.

Although the stratigraphic range chart (Table 1) cannot provide conclusive evidence to conform the proposed hypothesis of continuity and sediment mixing at Site 384, it illustrates clearly that the Cretaceous-Tertiary transition in Core 13 is fossiliferous throughout and that the Cretaceous nannoplankton assemblage is replaced by newly evolving taxa within less than 1 meter of sediment thickness.

More detailed evidence is provided by a quantitative taxonomic evaluation of the transitional assemblages. The computed relative abundances are based on counts of more than 300 individual nannoliths per sample and, in each sample, include 95 percent or more of all nannoliths present, whose maximum diameter exceeds 2 to $3 \mu \mathrm{m}$. This sample size provides a probability of 0.95 or more to encounter a specimen of a taxon whose true relative abundance in the population is 1 per cent. The extremely low relative abundances (less than $0.1 \%$ ) of some of the newly evolving taxa in the latest Maestrichtian sediments (above $168.20 \mathrm{~m}$ depth) shown in Table 1 are therefore not recognizable reliably in the sample sizes used. Those taxa found only at levels above 168.20 meters (the lowest occurrence of yellow nannolith chalk in Section 3 of Core 13) and which have not been recognized in the white nannolith chalk below 168.20 meters sub-bottom depth are considered to belong to the newly evolving Tertiary assemblage. All taxa occurring below 168.20 meters depth are considered to be Cretaceous.

A plot of the summed relative abundances of Tertiary taxa versus the summed relative abundances of the Cretaceous taxa is shown in Figure 1. Abundances of all Cretaceous species clearly taper off prior to the first occurrence of morphologically related Tertiary taxa as for instance in the genus Biscutum (compare with table $2 \mathrm{a}$ in Okada and Thierstein, this volume). On the average, an almost linear replacement of Cretaceous by Tertiary nannoliths is observed between 167.94 (the level of the color change in the sediment matrix) and 167.44 meters. The deviations from the average trend, i.e., relatively high percentages of Cretaceous nannoliths at 167.90 meters and at 167.76 to 167.80 meters are associated with nearby burrows, although all of these samples have been taken from the surrounding yellow matrix (Figure 1). The high abundance of Cretaceous taxa at 167.52 meters is not associated with visible lithologic changes at that level. As shown in Figure 1, the assemblages below the color change in the sediment matrix at 167.93 meters are all dominated $(98 \%$ or more) by Cretaceous taxa, regardless of whether they were taken from levels without darker domains or from levels with darker domains. A recently received 10-cc sample from 168.09 to 168.11 meters (see Figure 1) showed the following composition in the darker matrix: 92.7 per cent Cretaceous and 7.3 per cent Tertiary taxa and among the latter: Braarudosphaera spp., Crepidolithus spp. 1 per cent each, $C$. tenuis 4 per cent, $C$. primus 9 per cent, $M$. astroporus 14 per cent, $Z$. sigmoides 19 per cent, Thoracosphaera spp. 53 per cent. Similar taxonomic compositions are found at levels immediately above the color change in the

TABLE 2

Maximum and Minimum Thickness of Nannolith Zone NP 1 of Martini (1971) in Various DSDP Sites

\begin{tabular}{|c|c|c|c|c|}
\hline $\begin{array}{l}\text { DSDP } \\
\text { Site }\end{array}$ & $\begin{array}{l}\text { Minimum } \\
\text { Thickness } \\
\text { of NP } 1 \\
\text { (m) }\end{array}$ & $\begin{array}{l}\text { Maximum } \\
\text { Thickness } \\
\text { of NP } 1 \\
\text { (m) }\end{array}$ & Comment & Reference \\
\hline 208 & 0.18 & 0.28 & Very rare nannoliths & Edwards (1973) \\
\hline 216 & 0.00 & 0.16 & $=$ distance of sample spacing & Thierstein (unpublished) \\
\hline 217 & 0.00 & 3.00 & no recovery across boundary & Gartner (1974) \\
\hline 239 & 0.00 & 1.35 & $=$ distance of sample spacing & Schlich et al. (1974) \\
\hline 289 & 0.00 & 0.37 & $=$ distance of sample spacing & Thierstein (unpublished) \\
\hline 356 & 0.03 & 0.13 & $=$ distance of sample spacing & Thierstein (unpublished) \\
\hline 384 & 0.00 & 0.01 & $=$ distance of sample spacing & Okada and Thierstein (this vol.) \\
\hline 386 & 0.05 & 0.65 & $=$ distance of sample spacing & Okada and Thierstein (this vol.) \\
\hline
\end{tabular}


matrix at 167.92 meters. This evidence, together with the observation made on board immediately after opening of the core of stiffer darker clasts dispersed in a less lithified white matrix between $32 \mathrm{~cm}$ and $50 \mathrm{~cm}$ of Core 13 , Section 3 (167.92 to $168.20 \mathrm{~m}$ sub-bottom depth) indicate mechanical disturbance of the lithologic transition. Thus a total thickness of approximately 3 to $5 \mathrm{~cm}$ of darker Danian sediment from the level immediately below 167.92 meters depth may have been dispersed in the latest Maestrichtian chalks between 167.93 to 168.10 meters sub-bottom depth by drilling disturbance.

There remains still the question at which level the Cretaceous/Tertiary boundary is to be placed and whether the transition is continuous or contains a hiatus.

\section{Transition or Unconformity?}

Breaks in marine sedimentation between the Late Cretaceous and Paleocene that are exposed on continents have been reported by numerous authors (e.g., Loeblich and Tappan, 1957; Matsumoto, 1960; Premoli Silva and Luterbacher, 1966; Worsley, 1971, 1974). Apparent continuity of certain sections across the boundary also has been observed, e.g., by Bolli and Cita (1960), Luterbacher and Premoli Silva $(1962,1964)$; and Percival and Fischer (1977). When postulating an unconformity the dominant evidence is invariably paleontologic, i.e., the significant difference between late Maestrichtian and early Danian fossil assemblages, often combined with supporting lithologic evidence, such as hardgrounds and lithologic changes. Many of the cited unconformities could admittedly be of very short duration.

What are the criteria to support a claim of continuity of any sedimentary sequence? Essentially the absence of positive evidence for a hiatus, such as hardgrounds, changes in lithology, chemical composition, or fossils between two conformably stratified beds. An observed variation in any of these sediment properties can, however, also be explained by either paleoenvironmental or evolutionary changes. In addition, lithologic evidence of a hiatus may be obliterated by post-depositional sediment mixing by burrowing organisms.

Worsley (1974) estimated the extent of the Maestrichtian/ Danian unconformity to be about 9 meters in the Braggs section in Alabama by extending the relative abundance trend of Micula, assuming that this taxon was the last Cretaceous survivor and would comprise 100 per cent of the assemblage just prior to its extinction. This model involves the assumption of gradual extinctions of Cretaceous taxa at a more or less constant rate. A quantitative evaluation of nannofossils, using an independent sample set from the upper part of the Braggs section does not confirm Worsley's model of subsequent extinctions (Thierstein, unpublished).

The sedimentary transition at Site $\mathbf{3 8 4}$ lends itself to an independent test for continuity by using the paleomagnetic data provided by Larson and Opdyke (this volume). By comparing relative thickness of sediment between magnetic reversals to relative widths of synchronous magnetic stripes on the sea floor, it should become evident, whether part of the reversely magnetized polarity epoch Gubbio $\mathrm{G}^{-}$(Alvarez et al., 1977) which spans the Cretaceous/Tertiary boundary is missing. This test is of course valid only if it is assumed that spreading rates in various ocean basins and sedimentation rates in the sedimentary sequences did not change synchronously. Although increases in spreading rates may cause increases in oceanic sedimentation rates through greater tectonic activity at plate convergences leading to increased mountain building and erosion, it is assumed here that the link includes a time-lag exceeding 0.5 million years, which is the inferred duration of the Gubbio $\mathrm{G}^{-}$polarity epoch (LaBrecque et al., 1977).

The paleomagnetic measurements across the Cretaceous/Tertiary transition at Site $\mathbf{3 8 4}$ are discussed by Larson and Opdyke (this volume).

The magnetic record shows considerable scatter in inclinations and, as stated by Larson and Opdyke, is difficult to interpret. In translating these inclination measurements into a reversal sequence using the biostratigraphic information we arrive at an interpretation slightly different from that of Larson and Opdyke. The actual measurements are plotted in Figure 2, next to the interpretation given by Larson and Opdyke (their fig. 2).

The normally magnetized interval between 156.72 and 161.25 meters sub-bottom depth includes the lowermost occurrence of G. trinidadensis (Kaneps, this volume) which has been correlated in the Gubbio section with anomaly 28 (Alvarez et al., 1977). Anomaly 29 at Site 384 is considered to extend from 162.60 to 166.0 meters sub-bottom depth. This interval brackets the earliest occurrence of $C$. danicus between 163.0 and 163.60 meters depth. Anomaly 29 has been previously drilled at Site 245 where the oldest recovered nannolith assemblages belonged to the $C$. danicus Zone (Simpson, Schlich, et al., 1974, p. 198). The magnetic evidence immediately below 166.0 meters depth is different from that in the Gubbio section, where the paleontologic Cretaceous/Tertiary boundary lies in a reversely magnetized interval (Alvarez et al., 1977). At Site 384 a normally magnetized epoch covers the paleontologically defined Cretaceous/Tertiary boundary at $\mathbf{1 6 7 . 9 2}$ meters sub-bottom depth. Evidence for dating earlier polarity epochs is found at 173.60 and 174.80 meters depth where the lowermost $M$. mura and $A$. mayaroensis (McNulty, this volume) respectively, are recorded. The nannolith $M$. mura is present in basal sediments at Site 239 (Bukry, 1974) which was drilled east of Madagascar on crust formed during the late part of polarity epoch Gubbio E-, i.e., just prior to anomaly 31 (Schlich, 1974). The earliest occurrence of the planktonic foraminifer $A$. mayaroensis is correlated with magnetic anomaly 31 in the Gubbio section (Alvarez et al., 1977). Both appearances date the normally magnetized interval below 171.70 meters sub-bottom depth at Site $\mathbf{3 8 4}$ as anomaly 31 . By extrapolation, the next higher normally magnetized interval (from $171.10 \mathrm{~m}$ depth upwards) becomes anomaly 30 .

This leaves three possibilities open for the interpretation of the magnetic record between 164 and 170 meters. 


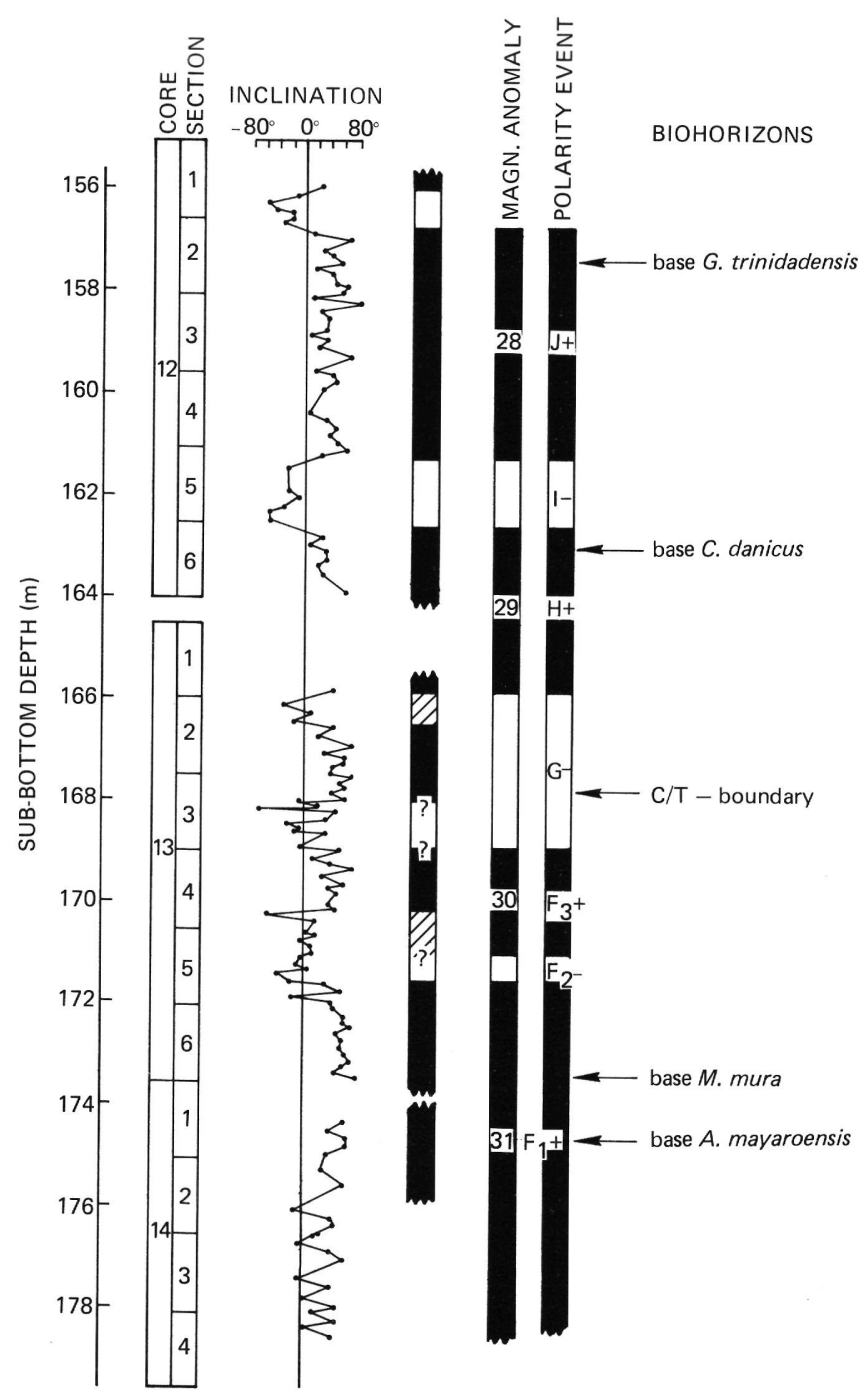

Figure 2. Magnetic and biostratigraphic interpretation at DSDP Site 384.

Either all reversals are recognized, which would leave a short normally magnetized interval within the Gubbio G- polarity epoch that has not been recorded at Gubbio and in most magnetic profiles from sea floors, or one of the reversely magnetized intervals ( 166.0 to $166.6 \mathrm{~m}$ and 168.1 to $169.05 \mathrm{~m}$ ) is not considered significant and the normally magnetized interval covering the $\mathrm{C} / \mathrm{T}$-boundary is joined to the adjacent normally magnetized epoch. Larson and Opdyke (this volume) have chosen to join this interval with the overlying epoch $\mathrm{H}+$ with the inference of a hiatus at the $\mathrm{C} / \mathrm{T}$-boundary. We prefer to recognize both reversely magnetized intervals and to leave the intermediate normal interval across the C/T-boundary as real for two independent reasons discussed in the following.

Firstly, the evolutionary patterns of the earliest Tertiary nannofossils between 167.92 and 167.20 meters depth (see below) are very similar to those observed in the Braggs section in Alabama and at DSDP Site 356 in the South Atlantic. The magnetic record at Site 356 suggests completeness of the earliest Tertiary sequence (D. Kent, L-DGO, personal communication). The earliest part of the Danian at Site 384 thus appears to be complete and lies above the base of the normally magnetized interval beginning at 168.10 meters depth. It therefore is highly unlikely that this level is the base of polarity epoch $\mathrm{H}+$, which lies within the G. pseudobulloides Zone in Gubbio (Alvarez et al., 1977). The first occurrence of $G$. pseudobulloides is observed at 166.25 meters depth at Site 384 (Kaneps, this volume). This also suggests that the base of epoch $\mathrm{H}+$ at Site 384 is at 166.0 meters depth. Extending the upper boundary of magnetic epoch $\mathrm{F}_{3}{ }^{+}$to 166.0 meters depth would lead to even worse inconsistencies. Considering the rather extensive paleontologic evidence, the least ambiguous interpretation of the magnetic record is the one shown in Figure 2.

A second argument for such an interpretation can be put forward by comparing the adopted magnetic stratigraphy at Site 384 with that of the Gubbio section (Alvarez et al., 1977) and with the widths of synchronous magnetic anomaly stripes on the ocean floor.

The widths of sea floor stripes between magnetic anomalies 28 and 31 have been measured from four profiles and are listed in Table 3: Column 1, North Pacific Ocean, profile B of Raff (1966), magnetic reversals picked as in Lowrie and Alvarez (1977); Column 2: Indian Ocean, profile V-1909 (= V-19 of Sclater and Fisher, 1974) reversals picked as in Lowrie and Alvarez (1977), South Atlantic Ocean; Column 3: profile C-1102 measured in Figure 2 of Lowrie and Alvarez (1977), and Column 4; profile V-20, recalculated using Table 1 in Heirtzler et al. (1968). Also shown in Table 3 are sediment thicknesses in meters of polarity events $\mathrm{F}_{1}{ }^{+}$ through $\mathrm{J}^{+}$in the Gubbio section (Columns 5 and 6) as given by Lowrie and Alvarez (1977) and Roggenthen and Napoleone (1977), respectively, as well as sediment thicknesses between reversals at Site 384 from Larson and Opdyke (this volume) in Column 7. Columns 8 through 10 in Table 3 show the measured thicknesses of the Cretaceous portion of the Gubbio G- polarity epoch in the Gubbio section and at Site 384. The comparison of the magnetic records at Site 384, Gubbio and on the ocean floors is done in the following two ways:

1) The relative widths from four ocean floor records and the two relative thickness measurements from the Gubbio section are averaged and compared with the relative sediment thicknesses at Site 384 (Figure 3). The thickness of the sediment that accumulated and the widths of the sea floor stripes have been normalized within the range of epochs $\mathrm{F}_{2}{ }^{+}$through $\mathrm{J}^{+}$. The comparison suggests that the Cretaceous/Tertiary transition (Epoch G-) at Site 384 and in Gubbio are relatively expanded in comparison to the average relative width of the reversed epoch between anomalies 29 and 30 on the sea floor. Changes in sedimentation rates at Site 384 and in the Gubbio section appear evident. At Site 384 sedimentation rate is relatively low in the latest Maestrichtian $\left(\mathrm{F}_{2}{ }^{+}\right.$and Cretaceous part of G-), whereas in the Gubbio section it is relatively low in the Danian (Tertiary part of G- and above).

2) To decrease the distortion introduced by possible worldwide changes in spreading rates the relative thickness of Epoch G- and its Cretaceous and Tertiary portions can be compared directly to the thicknesses of 
TABLE 3

Widths of Magnetic Stripes on Ocean Floor and Measured Thickness of Sediment of Contemporaneous Polarity Epochs (for details see text)

\begin{tabular}{|c|c|c|c|c|c|c|c|c|c|c|c|c|c|}
\hline \multirow{3}{*}{ 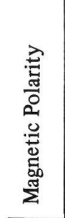 } & \multirow{3}{*}{ 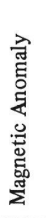 } & \multirow{3}{*}{ 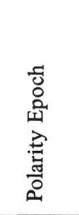 } & \multirow{3}{*}{ 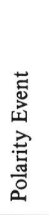 } & \multicolumn{4}{|c|}{ Sea Floor Width $(\mathrm{km})$} & \multicolumn{3}{|c|}{ Sediment Thickness (m) } & \multicolumn{3}{|c|}{$\begin{array}{c}\text { Cretaceous } \\
\text { and Tertiary } \\
\text { Part of G- }\end{array}$} \\
\hline & & & & \multirow{2}{*}{$\begin{array}{l}\text { North } \\
\text { Pacific } \\
\text { (1) }\end{array}$} & \multirow{2}{*}{$\begin{array}{c}\text { Indian } \\
\text { Ocean } \\
(2)\end{array}$} & \multicolumn{2}{|c|}{$\begin{array}{c}\text { South } \\
\text { Atlantic }\end{array}$} & \multicolumn{2}{|c|}{ Gubbio } & \multirow{2}{*}{$\begin{array}{c}\text { Site } 384 \\
(7) \\
\end{array}$} & \multicolumn{2}{|c|}{ Gubbio } & \multirow{2}{*}{$\begin{array}{c}\text { Site } 384 \\
(10)\end{array}$} \\
\hline & & & & & & (3) & (4) & (5) & (6) & & (8) & (9) & \\
\hline $1 / 8$ & 28 & $\begin{array}{c}\text { Gubbio } \\
\mathrm{J}+\end{array}$ & $\mathrm{J}+$ & 36.2 & 77.3 & & 14.1 & & 1.75 & 4.55 & & & \\
\hline & & $\begin{array}{c}\text { Gubbio } \\
\text { I- }\end{array}$ & I- & 16.9 & 38.1 & & 6.3 & & 0.5 & 1.35 & & & \\
\hline 17 & 29 & $\begin{array}{c}\text { Gubbio } \\
\mathrm{H}^{+}\end{array}$ & $\mathrm{H}+$ & 21.7 & 64.6 & & 11.4 & & 2.4 & 2.8 & & & \\
\hline & & $\begin{array}{c}\text { Gubbio } \\
\text { G- }\end{array}$ & G- & $\begin{array}{c}24.3 \\
(12.3 \%)\end{array}$ & $\begin{array}{c}57.2 \\
(13.4 \%)\end{array}$ & 11.5 & $\begin{array}{c}9.3 \\
(11.3 \%)\end{array}$ & 6.0 & $\begin{array}{c}5.25 \\
(17.8 \%)\end{array}$ & $\begin{array}{c}3.0 \\
(14.2 \%)\end{array}$ & 1.4 & 1.05 & \\
\hline 770 & 30 & & $\mathrm{~F}_{3}+$ & 56.4 & 129.5 & 34.6 & 22.6 & 6.8 & 8.2 & 2.1 & & & \\
\hline & & $\begin{array}{c}\text { Gubbio } \\
\text { F+ }\end{array}$ & $\mathrm{F}_{2^{-}}$ & 7.9 & 11.4 & 3.1 & 1.9 & 0.3 & 0.1 & 0.6 & & & \\
\hline & 31 & & $\mathrm{~F}_{1}+$ & 34.0 & 49.4 & 26.9 & 16.9 & 10.9 & 11.0 & $>6.8$ & & & \\
\hline
\end{tabular}

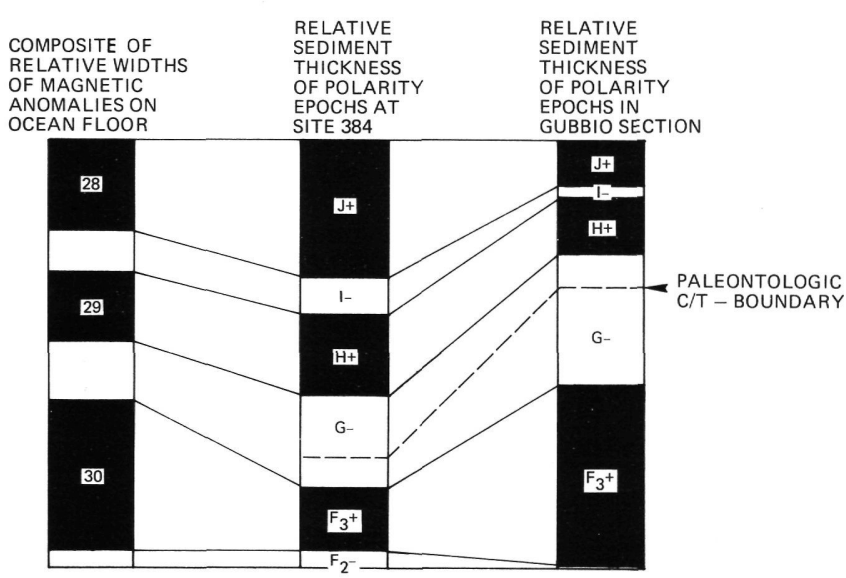

Figure 3. Normalized relative thicknesses of magnetic epochs $F$ through J (anomalies 31 through 28).

neighboring epochs (Table 4). The ratios of the stripe widths on the ocean floors as well as of the thicknesses in the Gubbio sections are averaged to their geometric means. Geometric rather than arithmetic means are used because ratios are averaged (Mills, 1938) and arithmetic means would not meet the reversal test (Fisher, 1922); i.e., the arithmetic mean of reversal ratios is not equal to the inverse of the arithmetic means of the inverse ratios, but the geometric mean is. The data in Table 4 show that the ratios $\mathrm{H}^{+} / \mathrm{G}_{\mathrm{T}^{-}}$and $\mathrm{F}_{3}+/ \mathrm{G}_{\mathrm{C}^{-}}$at Site 384 and Gubbio are quite similar. In both sections the change in sedimentation rate occurs very close to the Cretaceous/Tertiary boundary, although, in the opposite sense. The factor of relative expansion of G- at Site 384 compared to the averaged sea floor record is 1.2 times for $\mathrm{G}-: \mathrm{H}^{+}$and $\mathrm{G}-: \mathrm{F}_{2}-1.5$ times for $\mathrm{G}-\mathrm{:}: \mathrm{I}-$, and 3.6 times for $\mathrm{G}-: \mathrm{F}_{3^{+}}$.

\section{Mass Extinction and Sediment Mixing}

If the sediment record at Site 384 is indeed continuous, a detailed study of the replacement mechanism of the nannolith assemblages at the Maestrichtian/Danian boundary may be conducted.

As previously shown (Figure 1) the abundance of Cretaceous taxa decreases gradually between 167.93 and 167.10 meters. Is this transition, as evidenced in the sedimentary record, indicative of a former gradual replacement of Cretaceous nannoplankton by newly

TABLE 4

Ratios of Widths and Thicknesses of Polarity Epochs Calculated From Table 2

(for details see text) $\left(\mathrm{G}_{\mathrm{T}}=\right.$ Tertiary part of $\mathrm{G}$ Epoch, $\mathrm{G}_{\mathrm{C}}=$ Cretaceous part of $\mathrm{G}$ Epoch)

\begin{tabular}{|c|c|c|c|c|c|c|c|c|c|}
\hline \multirow[t]{2}{*}{ Ratio } & \multirow{2}{*}{$\begin{array}{c}\begin{array}{c}\text { North } \\
\text { Pacific }\end{array} \\
(1)\end{array}$} & \multirow{2}{*}{$\begin{array}{c}\text { Indian } \\
\text { Ocean }\end{array}$} & \multicolumn{2}{|c|}{$\begin{array}{c}\text { South } \\
\text { Atlantic }\end{array}$} & \multirow[t]{2}{*}{$\begin{array}{l}\text { Geom. Mean } \\
(1-4)\end{array}$} & \multicolumn{2}{|c|}{ Gubbio } & \multirow[t]{2}{*}{$\begin{array}{c}\text { Geom. Mean } \\
(5,6)\end{array}$} & \multirow[t]{2}{*}{ Site 384} \\
\hline & & & (3) & (4) & & (5) & (6) & & \\
\hline I-/G- & 0.70 & 0.67 & & 0.68 & 0.68 & & 0.10 & & 0.45 \\
\hline $\mathrm{H}+/ \mathrm{G}-$ & 0.89 & 1.13 & & 1.23 & 1.07 & & 0.46 & & 0.93 \\
\hline $\mathrm{F}_{3}+/ \mathrm{G}-$ & 2.32 & 2.26 & 3.01 & 2.43 & 2.49 & 1.13 & 1.56 & 1.33 & 0.70 \\
\hline $\mathrm{F}_{2-/ \mathrm{G}-}$ & 0.33 & 0.20 & 0.27 & 0.20 & 0.24 & 0.05 & 0.02 & 0.03 & 0.20 \\
\hline $\mathrm{H}+/ \mathrm{G}_{\mathrm{T}^{-}}$ & & & & & & & 1.45 & & 1.39 \\
\hline $\mathrm{F}_{3}{ }^{+/ \mathrm{G}_{\mathrm{C}^{-}}}$ & & & & & & 1.48 & 2.28 & 1.84 & 1.94 \\
\hline
\end{tabular}


evolving Tertiary taxa or is the "transitional" record at Site 384 the result of sediment mixing which obscures the original instantaneous replacement? If the replacement had been gradual, due to increasing competition for dwindling nutrients or due to climatic change, for example, a sequence of extinctions or at least relative abundance changes of the succumbing Cretaceous taxa should be recognizable in the record. The relative abundances within the Cretaceous assemblage, however, do not change significantly in the transitional interval (Figure 4). The observed patterns therefore appear to indicate that all Cretaceous taxa became extinct simultaneously and were subsequently diluted by and reworked into Tertiary sediment through the activity of benthic burrowers.

Assuming a sudden extinction of all Cretaceous taxa (which, of course, could not be distinguished paleontologically from a hiatus) it can be tested whether the observed abundance patterns are compatible with those expected from various mixing models, as proposed by Berger and Heath (1968), Ruddiman and Glover (1972), and Guinasso and Schink (1975). The expected record of a sudden original replacement of the nannoflora could be any one of three different types depending on the degree of mixing (Figure 5). A comparison of these curves with the relative abundances of Cretaceous versus Tertiary taxa (Figure 1) suggests that the record at Site 384 may be the result of partial mixing across the Cretaceous/Tertiary boundary. Complete homogenization of the mixed layer would result in an exponentially decreasing frequency of the Cretaceous assemblage from a point one mixed layer thickness below its timestratigraphic extinction level as described by Berger and Heath (1968):

$$
P_{D}=P_{0} \exp \left(-D / m^{\prime}\right)
$$

where $\mathrm{P}_{\mathrm{D}}$ is the concentration of Cretaceous nannoliths in the sediment deposited after sediment of thickness D has been deposited on the layer with the original concentration $\mathrm{P}_{\mathrm{O}}$ (at the base of the homogeneous layer), $\mathrm{m}^{\prime}$ being the thickness of the homogeneous layer. The slope of the curve is a measure of the thickness of the mixed layer ( = virtual mixing length of Berger, 1976):

$$
\mathrm{m}^{\prime}=\mathrm{D} /\left(1 \mathrm{n} \mathrm{P}_{\mathrm{o}} \mathrm{s}-1 \mathrm{n} \mathrm{P}_{\mathrm{D}}\right) \text {. }
$$

For complete mixing a constant value of $\mathrm{m}^{\prime}$ is obtained when measured anywhere along the slope. At Site 384 , however, the virtual mixing length is variable (Figure 6), i.e.

$$
\begin{aligned}
& \mathrm{m}_{\mathrm{A}}^{\prime}= \begin{array}{l}
26.2 \mathrm{~cm} \text { from } 167.20 \text { to } 167.97 \text { meters } \\
\text { sub-bottom depth }
\end{array} \\
& \mathrm{m}_{\mathrm{B}}^{\prime}= \begin{array}{l}
20.5 \mathrm{~cm} \text { from } 167.20 \text { to } 167.76 \text { meters } \\
\text { sub-bottom depth }
\end{array} \\
& \mathrm{m}^{\prime}{ }_{\mathrm{C}}=\begin{array}{l}
17.5 \mathrm{~cm} \text { from } 167.20 \text { to } 167.60 \text { meters } \\
\text { sub-bottom depth. }
\end{array}
\end{aligned}
$$

There are three obvious explanations for this effect: (1) The thickness of a completely homogenized mixed layer decreased through the earliest Paleocene, (2) the sedimentation rate increased through the earliest Paleocene preventing complete homogenization, and (3) the mixed layer was not homogenized completely because of changes in the benthic community. Incomplete mixing would result in a steepening of the abundance gradient over the middle part of the slope (Figure 6) and thus yield smaller virtual mixing lengths. The use of the slope of the decreasing abundance of Cretaceous taxa in percent of the total nannolith assemblage (Cretaceous and Tertiary) presumes that there was no significant interruption in the arrival of nannoliths at the sediment/ water interface between the Cretaceous extinctions and the earliest Tertiary appearances. This may indeed be the case, since at least some of the early Tertiary taxa have been observed repeatedly in late Maestrichtian sediments and may have occupied rather rapidly the ecospace vacated by the extinct Cretaceous plankton.

In an analysis of the statistical properties of tracer distributions of an instantaneous event under different mixing parameters, Guinasso and Schink (1975) showed that the weighted mean depth of the tracer after mixing is always at the level of the original impulse concentration, regardless of the extent of mixing (see in particular Guinasso and Schink, 1975, Figure 2). The original impulse can be equated at Site 384 to the highest level in the sedimentary column, where 100 per cent Cretaceous taxa reached the sediment/water interface, just prior to their extinction.

The weighted mean depth of the distribution of Cretaceous taxa in the transitional interval from 167.20 to 167.92 meters, including the clast found at 168.10 meters and assuming its original position was at 167.97 meters, is at 167.76 meters. This level is the best estimate for the original position of the Cretaceous extinctions. The sediment between 167.76 meters and the level of the lowermost original position of dark ooze at 167.97 meters represents the mixed layer at the time of the extinctions and is $21 \mathrm{~cm}$ thick. This measure is close to the mixed-layer thickness determined previously (Figure 6) under the assumption of complete mixing between 167.20 and 167.76 meters sub-bottom depth.

\section{Evolution of Earliest Tertiary Nannofossils}

The evolutionary succession of earliest Tertiary nannoliths can be visualized by plotting relative abundances of Tertiary taxa in per cent of the Tertiary assemblage (Figure 7). The very rare occurrences of Tertiary specimens in a few samples from the white matrix below 167.92 meters sub-bottom depth cannot be subjected to quantitative analysis. It has been shown that the nannolith record at Site 384 appears to be complete and is most likely the result of an instantaneous extinction of the Cretaceous nannoflora, masked in the sedimentary record by partial benthic mixing. It is thus justified to ignore the Cretaceous portion of the nannofossil assemblages in an analysis of the evolutionary patterns of the Tertiary taxa, since it is irrelevant to this analysis, what 



Figure 4. Relative abundance of Cretaceous nannolith taxa shown as per cent of total Cretaceous assemblage at DSDP Site 384. Cretaceous/Tertiary boundary at 167.92 meters depth, lowermost occurrence of $\mathrm{M}$. mura at 173.60 meters and of $\mathrm{N}$. frequens at 172.00 meters depth. Listed are taxa (in alphabetic order of specific epithet) with a minimum abundance of 2 per cent in at least one sample. Abbreviated names are given in full in Table 1 except for last column. which shows number of empty nannolith shields. 


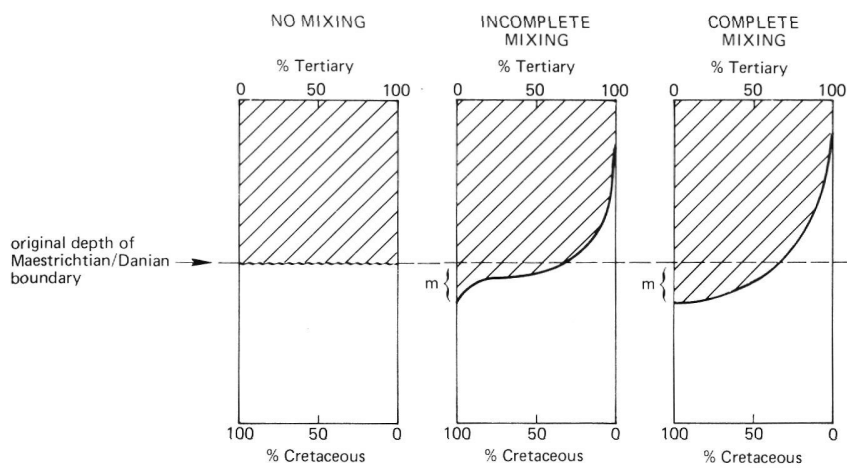

Figure 5. Resulting nannolith distributions under different intensities of benthic mixing across a mass-extinction or a hiatus.

the nature of the latest Maestrichtian sediment particles was, into which the earliest Tertiary nannofossils were mixed. The lowermost levels of the Tertiary record (167.97 to $167.88 \mathrm{~m}$ ) are dominated by Thoracosphaera, Z. sigmoides, and M. astroporus. A Braarudosphaera dominance is observed between 167.86 and 167.76 meters sub-bottom depth, with a subsequent increase of Cruciplacolithus primus and $C$. tenuis. The relative abundance distribution of Braarudosphaera (Figure 7) approximates an expected distribution curve for an instantaneous Braarudosphera bloom, assuming incomplete benthic mixing (Ruddiman and Glover, 1972, figure 7; Guinasso and Schink, 1975, figure 2; Berger, 1976, figures 29,36 ). The mean weighted depth of the Braarudosphaera distribution, which is equal to the level of the original impulse regardless of the degree of mixing (Guinasso and Schink, 1975) has been calculated for the area between 167.20 and 167.97 meters and lies at 167.71 meters; i.e., $5 \mathrm{~cm}$ above the calculated original level of the Cretaceous extinctions and $21 \mathrm{~cm}$ above the color change in the matrix. Using the slope of the Braarudosphaera abundance decrease between 167.82 and 167.20 meters, a mixed-layer thickness of $21.1 \mathrm{~cm}$ results (Berger, 1976) which is in close agreement with the mixing length calculated from the distribution of the Cretaceous taxa and suggests an abrupt end of the Braarudosphaera bloom.

The highest abundance of 49.1 per cent suggests that either the Braarudosphaera bloom lasted for a minimum time period represented by a few centimeters of sediment deposition or that the influx of Braarudosphaera resulted in temporarily increased sedimentation rates.

\section{FLUCTUATIONS OF THE CARBONATE LINE IN THE MESOZOIC}

The observed variations of carbonate contents and nannolith preservation in Mesozoic sediments recovered during Leg 43 suggest considerable changes in carbonate deposition patterns in the North Atlantic. The sedimentary records of DSDP Sites $382,384,385$, and 386 greatly improve the previously poorly known Mesozoic carbonate history of the North Atlantic as given by van Andel (1975). Procedures for estimating ages of oceanic crust and depositional paleodepths and their errors have

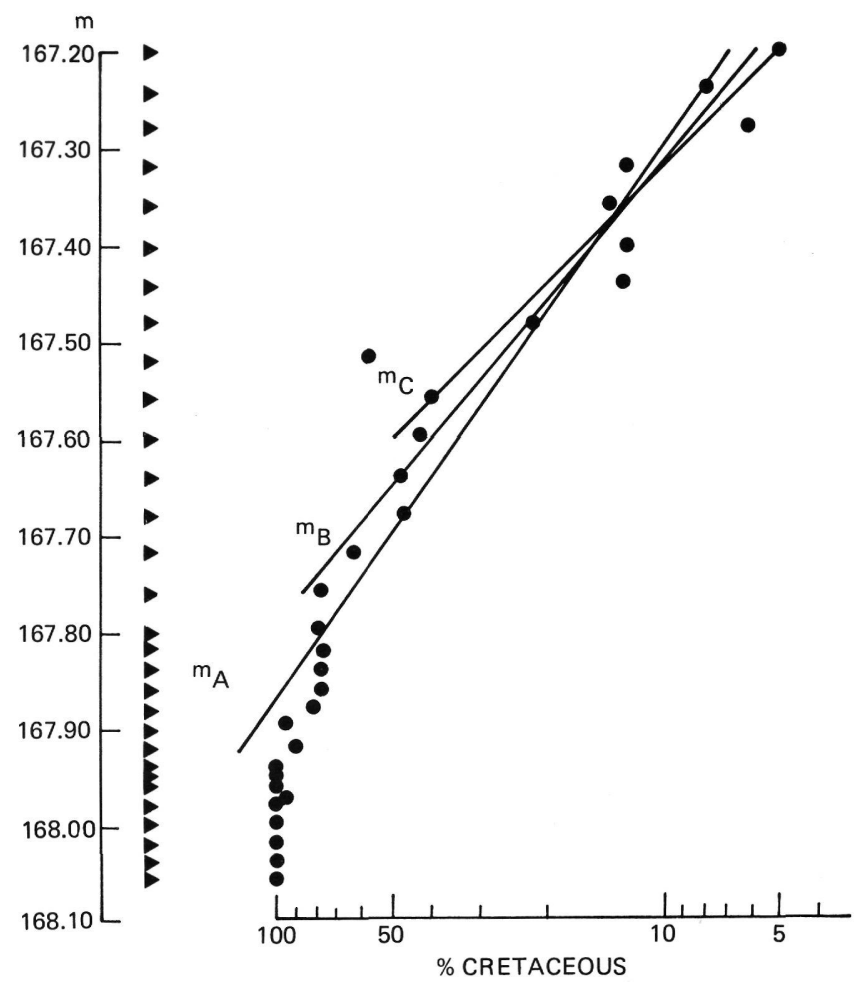

Figure 6. Calculated virtual mixing lengths using Berger and Heath's (1968) mixing model $\left(m\right.$ ' $\left.=D / \ln P_{o}-\ln P_{D}\right)$ at DSDP Site 384: $m_{A}=26.2 \mathrm{~cm}$ (calculated from 167.20 to $167.97 \mathrm{~m}$ sub-bottom depth), $m_{B}=20.5 \mathrm{~cm}$ (calculated from 167.20 to $167.76 \mathrm{~m}), m_{c}=17.5 \mathrm{~cm}(\mathrm{cal}$ culated from 167.20 to $167.60 \mathrm{~m}$ ).

been discussed in detail by Berger $(1972,1973)$, Berger and Winterer (1974), van Andel (1972), and van Andel and Bukry (1973). Backtracking of old pre-Cenozoic crust is particularly sensitive to one source of error: the uncertainty of absolute ages assigned to biostratigraphic data extracted from the lowermost fossiliferous sediments and to the magnetic anomaly identified on the ocean floor around the drill site. This age error is usually considerably larger than other errors introduced by (a) the thickness of biostratigraphic zones; (b) a possible hiatus between basalt emplacement and oldest sediment (Berger and von Rad, 1972); (c) extrapolation of sedimentation rates for unfossiliferous basal sediments; (d) uncertainties of depth determinations in DSDP holes (van Andel, 1972; van Andel and Bukry, 1973); and (e) ambiguities in assessing the average initial ridge crest elevation (i.e., shape of generalized subsidence curve). The empirically derived age-depth curve of Sclater et al. (1971) has been used for the paleodepth estimates shown in Figures 8 and 9, and correction for sediment loading was done following Berger and Winterer's (1974) method. Paleodepths for maximum and minimum absolute ages as determined from various sources (e.g., Larson and Hilde, 1975; Thierstein, 1976; van Hinte, 1976a,b) have been determined for all sites, but have been reduced to their average in Figure 9 . The basement age ranges of the western North Atlantic sites were determined in the following way: 


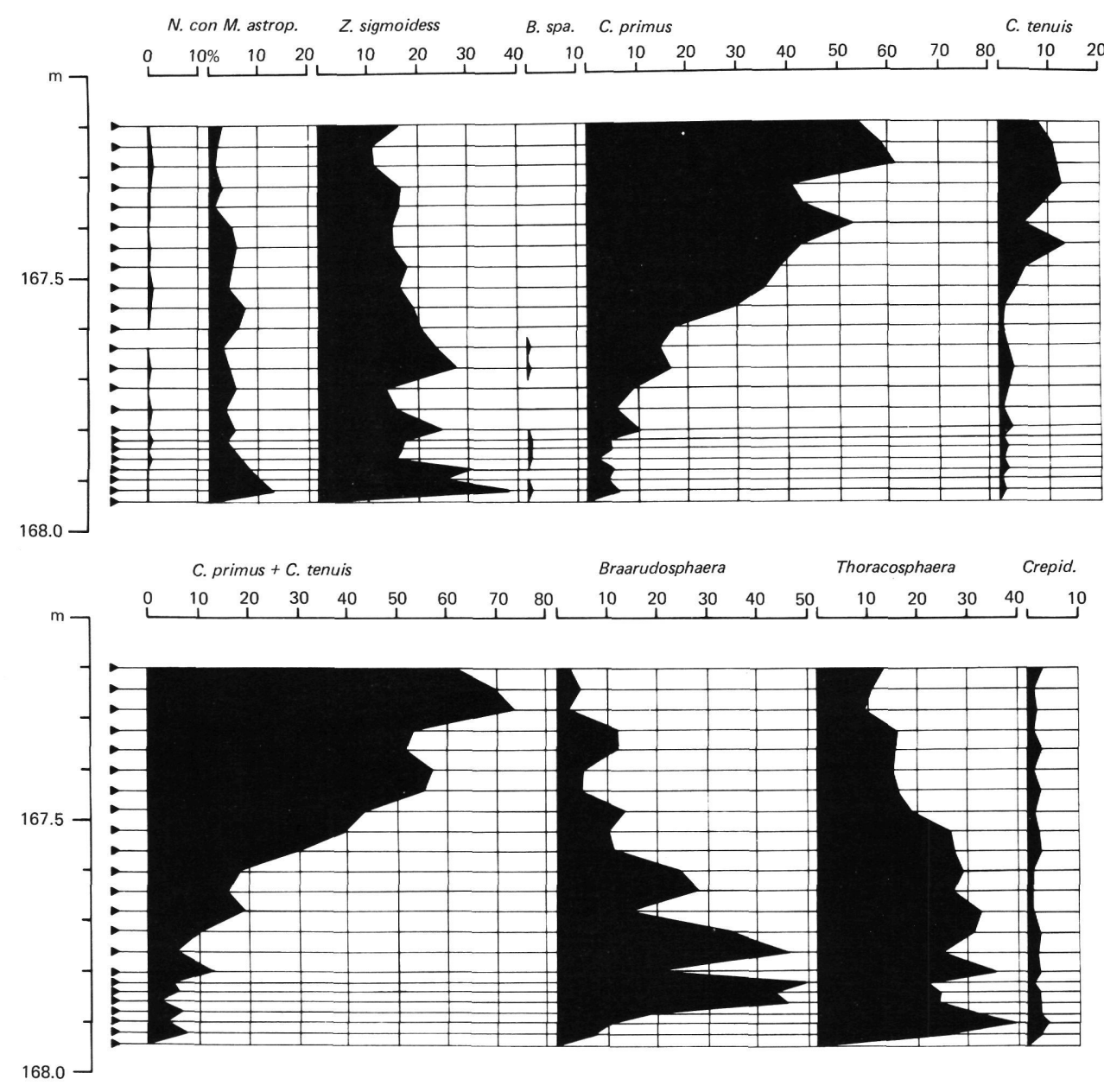

Figure 7. Relative abundance of Tertiary nannolith taxa above 167.94 meters subbottom depth shown as per cent of total Tertiary assemblage at DSDP Site 384. Cretaceous/Tertiary boundary between lowermost two samples. Composition of dislocated assemblage found at 168.10 meters not shown (in text). Abbreviated names are given in full in Table 1.

Site 10, drilled in the older part of Anomaly 33 (Cande and Kristoffersen, 1977), yielded middle Campanian nannoliths and foraminifers immediately overlying basaltic basement. Age estimates for the older part of anomaly 33 range from 70 m.y. (van Andel, 1975) to 76 m.y. (Cande and Kristoffersen, 1977), the biochronologic ages range from 74 to $78 \mathrm{~m} . \mathrm{y}$. using planktonic foraminifers (Cita and Gartner, 1971, van Hinte, 1976) and from 73 to 77 m.y. using nannofossils (Cita and Gartner, 1971; Thierstein, 1976). Assumed age range in Figure 8 is 70 to 78 m.y.

Site 105 , located on crust slightly younger than anomaly $M-25$ (Larson and Hilde, 1975), yielded Oxfordian nannoliths above the basement (Wilcoxon, 1972; Thierstein, 1976). The inferred paleomagnetic basement age is 150 to 152 m.y. (Larson and Hilde, 1975) and the inferred paleontologic age is 150 to 156 m.y. (Thierstein, 1976).

Site 382 lies halfway between anomaly $M-4$ and DSDP Site 10. Age estimates for $M$-4 range from 117 m.y. (Larson and Hilde, 1975) to 114 m.y. (Thierstein, 1976), those for Site 10 from 78 m.y. to 70 m.y. The resulting maximum crustal age for Site 382 thus is [ $(117$ $-78) / 2]+78=97.5$ m.y., the minimum [(114 70) $/ 2]+70=92$ m.y.

Site 384 , located on anomaly $M-1$ has an estimated age range from 113 m.y. (Larson and Hilde, 1975) to 107 m.y. (Thierstein, 1976).

Site 385 was assumed by the shipboard party to be on crust 125 m.y. old (Tucholke and Vogt, this volume). If inferred from the relative distances of Site 385 from the magnetic quiet zone and anomaly $\mathrm{J}$ as shown by Pitman and Talwani (1972) and from the assumed basement age of Site 382, an extrapolated age of $135 \mathrm{~m}$.y. for the crust at Site 385 is obtained. These two values have been used in Figure 8.

Site 386 is located near the lower end of the "Cretaceous magnetic smooth" zone with a basement age around 106 m.y. (Larson and Hilde, 1975). The oldest fossils from sediments 3 meters above basaltic basement are of early to middle Albian age, i.e., about 107 m.y. (van Hinte, 1976) to $101 \mathrm{~m} . y$. (Thierstein, 1976).

Site 387 was drilled near anomaly $M-16$ which is 135 to $136 \mathrm{~m}$.y. old (Larson and Hilde, 1975). The oldest 


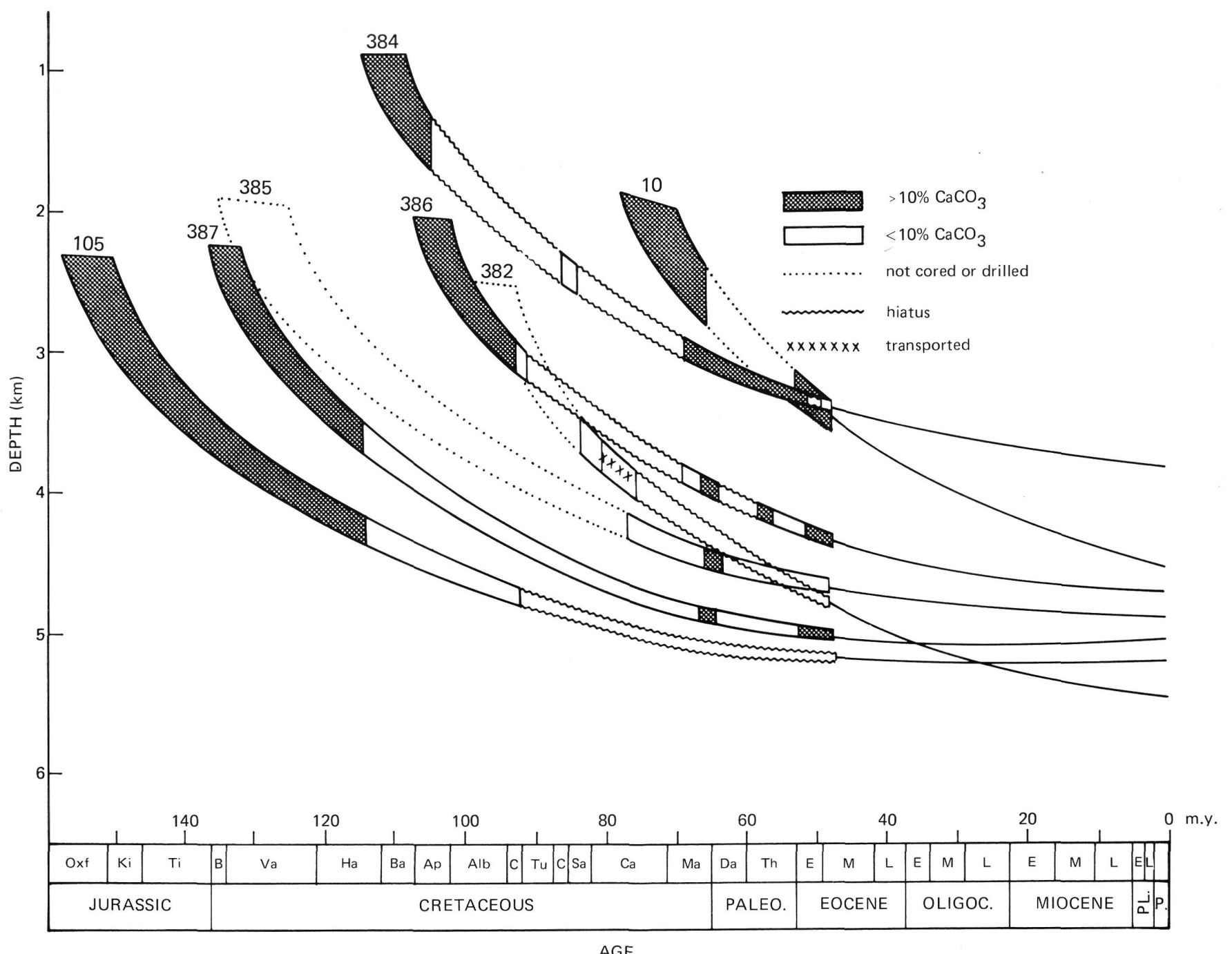

Figure 8. Paleodepth and facies of western North Atlantic DSDP sites. Widths of tracks indicate uncertainty of absolute age of basement.

nannolith assemblage from a pocket ooze in the basalt yields an age of 133 to 135 m.y. (Thierstein, 1976).

It is apparent from the lithologic evidence shown in Figure 7, that the carbonate line in the western North Atlantic shoaled from about $4.3 \mathrm{~km}$ depth in the Hauterivian to $2.8 \mathrm{~km}$ in the Cenomanian and to less than $2 \mathrm{~km}$ in the Santonian. A very abrupt deepening in the middle Maestrichtian to depths of $5 \mathrm{~km}$ or more lasted for less than $3 \mathrm{~m} . \mathrm{y}$. and covers the Cretaceous/ Tertiary boundary. The carbonate line shoaled in the Paleocene to depths between 3 and $4 \mathrm{~km}$. This evidence does not confirm the models previously proposed by Tappan (1968) and extended by Worsley $(1971,1974)$, who advocated an increase in carbon dioxide in atmosphere and oceans at the end of the Cretaceous.

Where did all the carbonate come from that was suddenly dumped into the deep North Atlantic basin? Geographic variation in the depth of the carbonate compensation surface in the modern ocean appear to be caused by a number of different factors such as inter-ocean deep-water fractionation, shelf and marginal sea versus open ocean fractionation and fractionation related to latitude, productivity, diversity (see review by Berger and Winterer, 1973), grazers (Honjo, 1976; Roth et al., 1975), and biomineralization (e.g., aragonite versus calcite tests). Any one or any combination of these may have been involved in causing the observed North Atlantic carbonate excursion. A readily available test can be performed by analyzing the carbonate records of other deep sea drilling sites with Mesozoic paleodepths exceeding $2 \mathrm{~km}$. A composite plot showing the subsidence curve for the median of the calculated age range of the basement is given in Figure 9. All sites except Site 212 have been backtracked from their present depths. Site 212, located in the Wharton Basin (eastern Indian Ocean) was drilled in 6243 meters water depth (von der Borch, Sclater, et al., 1974). A late Maestrichtian chalk unit of 51.5 meters thickness was recovered 34 meters above basaltic basement. The unit was interpreted as being transported from nearby shallower areas by Pimm (1974, p. 769). Examination of Sclater and Fisher's (1971) bathymetric map shows the shallowest elevations within a radius of over $200 \mathrm{~km}$ to be at 5500 meters. Therefore a present 5500 meters minimum depth for the 


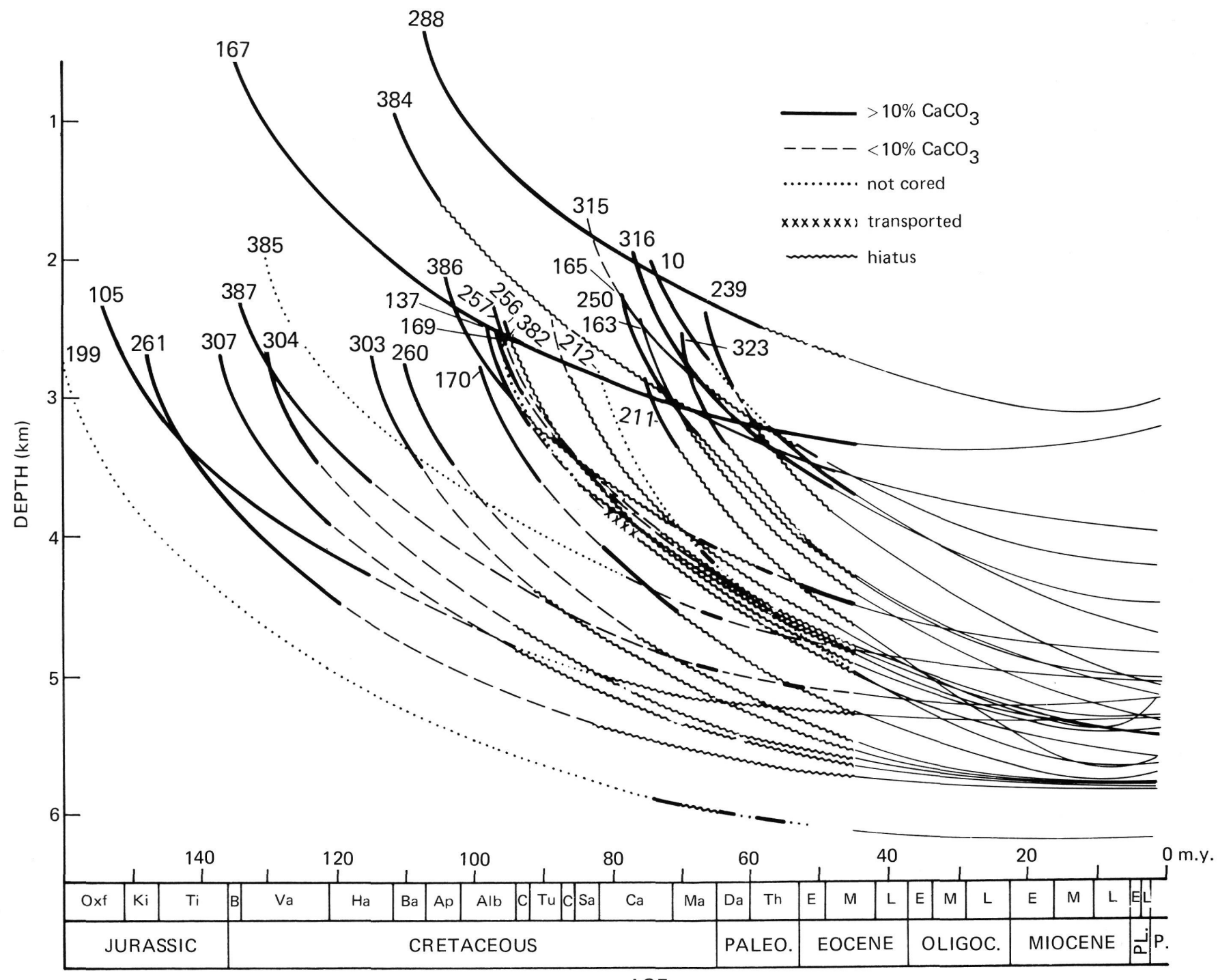

AGE

Figure 9. Paleodepth and facies of Mesozoic DSDP sites (Legs 1-35 and 43) with Mesozoic paleodepths exceeding $2 \mathrm{~km}$.

possible source area of the late Maestrichtian carbonates at Site 212 is shown in Figure 9. Basement age range for Site 212 follows Johnson et al. (1976).

The documented movements of the Early and Middle Cretaceous carbonate compensation surface in the Indian and Pacific oceans appear to follow the North Atlantic pattern. Most of the sites in the Indian and Pacific oceans with paleodepths exceeding $3 \mathrm{~km}$ at the Cretaceous/Tertiary boundary show hiatuses beginning in the Late Cretaceous and extending well into the Paleogene. The deep sites with dated sedimentary records near the Cretaceous/Tertiary boundary are discussed individually.

Sites 169 and 170 were drilled in the Central Pacific (Winterer, Ewing, et al., 1973) and recovered a scanty Campanian to early Maestrichtian record. There appears to be some evidence for possible transport of rare foraminifers at Site 170 (Douglas, 1973). No mixing of nannofossils was observed in these cores, and it remains ambiguous whether the sediments are in place or not. Corroborative evidence from these two sites and from
Site 164 led Winterer (1973, p. 921) to believe that the CCD in the Pacific deepened to around 4500 meters in the late Campanian and early Maestrichtian.

Site 199, located in the Caroline Abyssal Plain (eastern Central Pacific), yielded a carbonate sequence of late Campanian/early Maestrichtian age which is separated by a lithologically inconspicuous hiatus from middle Danian carbonates. Re-examination of closely spaced nannofossil samples in Core 11 did not confirm the presence of Micula mura Zone, as postulated by Hekel (1973). Samples 199-12-1, $70 \mathrm{~cm}, 199-11-2,50$ $\mathrm{cm}, 31 \mathrm{~cm}$, and $18 \mathrm{~cm}$, and 199-11-1, $148 \mathrm{~cm}$ all yield assemblages of the Tetralithus trifidus Zone (including T. trifidus and Broinsonia parca and neither Lithraphidites quadratus nor M. mura). Sample 199-11-1, 140 $\mathrm{cm}$ contains $C$. tenuis and $C$. pelagicus $s$. ampl. and Chiasmolithus danicus, besides abundantly reworked Cretaceous taxa (e.g., M. mura, T. trifidus, and B. par$c a$ ). Reworking appears to occur only in the Danian. Transport of the carbonate from nearby shallower areas cannot be excluded. 
Site 212, in the eastern Indian Ocean, documents a deepening of the carbonate compensation depth to about $4 \mathrm{~km}$ in the latest Maestrichtian, even if the sediments are assumed to be transported from nearby shallower elevations (see discussion above). If the carbonate record were in place, the excursion of the carbonate line would have been closer to $5 \mathrm{~km}$ depth. Direct evidence for a shallower origin of this unit is quite meager and was mainly based on the considerable thickness of the latest Maestrichtian sequence and on extrapolation from younger turbidite intervals encountered at this site (Pimm, 1974).

Site 257 was drilled in the Wharton Basin (eastern Indian Ocean) and yielded a dated noncalcareous Late Cretaceous sequence as young as Campanian (Herb, 1974).

The presently available evidence indicates a possible deep-water fractionation between the Pacific and the
Atlantic and Indian oceans (Figures 10 and 11) in late Mesozoic time. The carbonate compensation surface deepened between the Turonian and Campanian in the tropical Pacific, by at least $1 \mathrm{~km}$, possibly $3 \mathrm{~km}$. The scanty carbonate record from Site 199 predates and postdates the carbonate sediments deposited in the North Atlantic. No autochthonous and continuous record across the Cretaceous/Tertiary boundary from paleodepths exceeding $3 \mathrm{~km}$ is known from the Pacific. A sudden excursion of the carbonate line into the deep North Atlantic from about $2.5 \mathrm{~km}$ in the Santonian to 5 $\mathrm{km}$ or more (compare also Tucholke and Vogt, this volume) in the middle Maestrichtian lasted into the earliest Danian with a subsequent shallowing to about $4 \mathrm{~km}$ depth. In the Indian Ocean, the carbonate compensation surface deepened from about $2.5 \mathrm{~km}$ in Santonian time to over $4 \mathrm{~km}$ in the latest Maestrichtian and shallowed to about $3 \mathrm{~km}$ in the middle Paleocene.

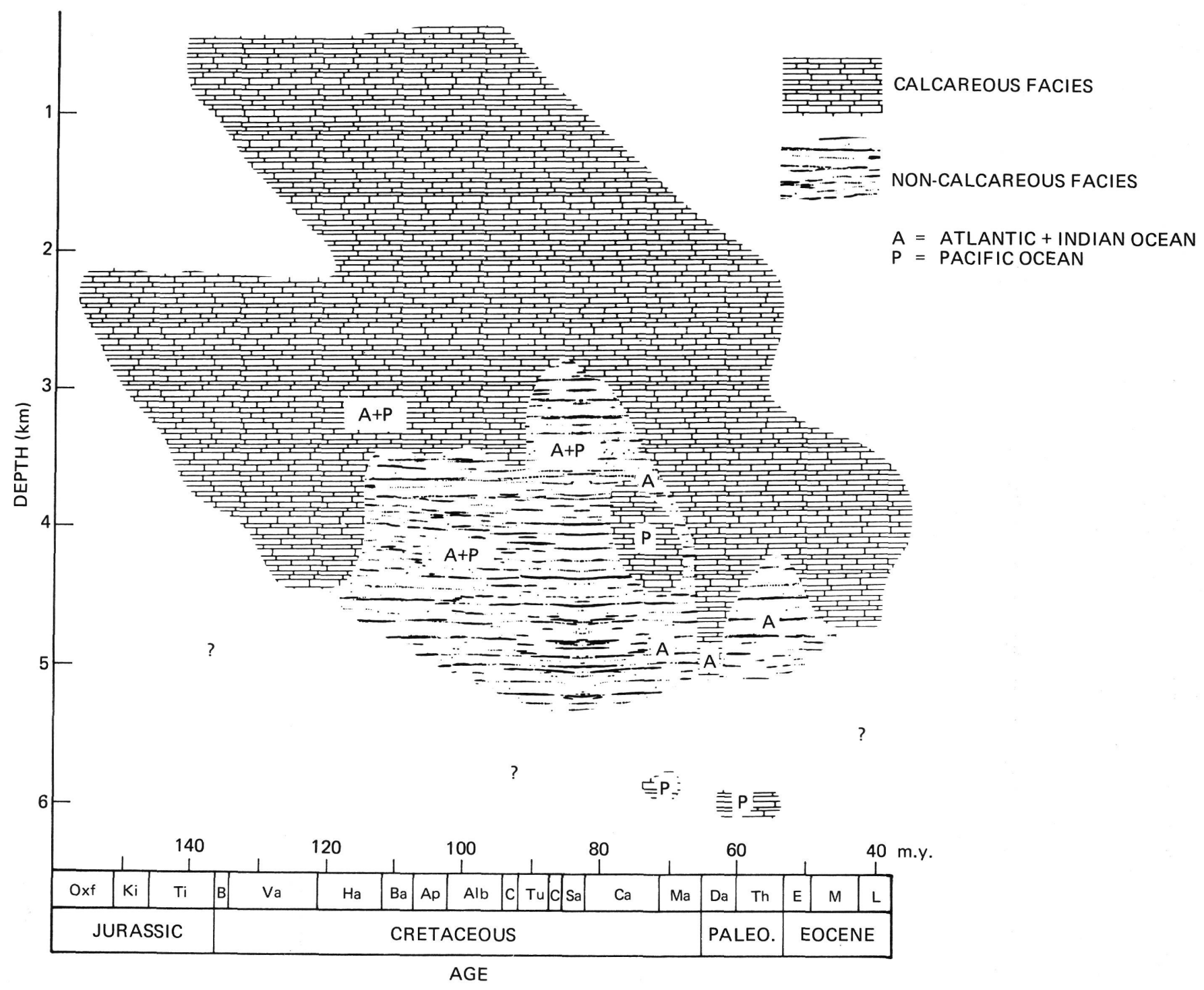

Figure 10. Composite facies plot from DSDP Legs 1-35 and 43. A = Atlantic and Indian Ocean evidence, P=Pacific Ocean evidence. 


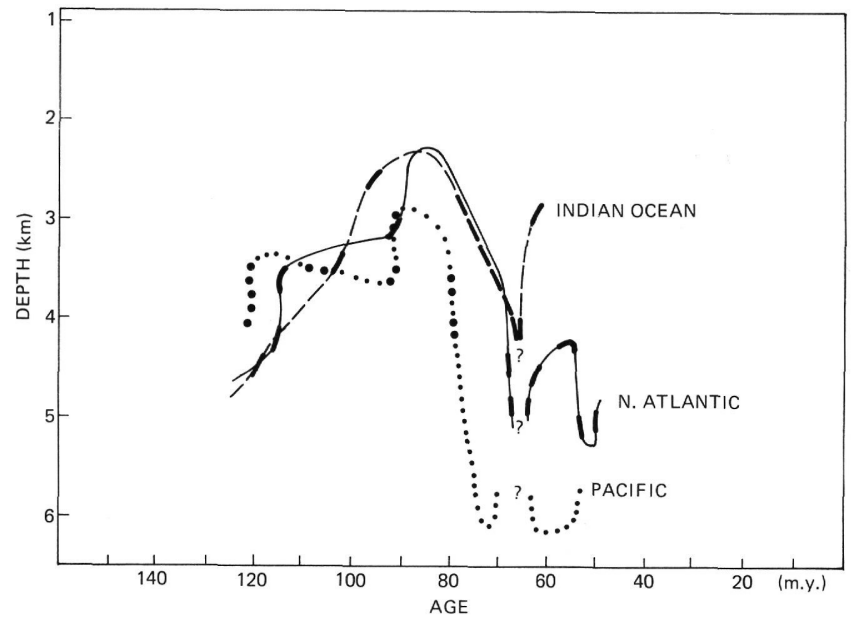

Figure 11. Documented (heavy signatures) and extrapolated (light signatures) fluctuations of the carbonate line in Mesozoic and Paleocene ocean basins.

\section{ACKNOWLEDGMENTS}

Research supported by the National Science Foundation under Grants DES75-20077 and OCE76-22150, and partially through a post-doctoral fellowship to H. R. Thierstein by the Schweizerischer Nationalfonds. Core materials were made available by the Deep Sea Drilling Project. Reviews by W. H. Berger and D. Bukry are acknowledged.

\section{REFERENCES}

Alvarez, W., Arthur, M. A., Fischer, A. G., Lowrie, W., Napoleone, G., Premoli Silva, I., Roggenthen, W. M., 1977. Upper Cretaceous-Paleocene magnetic stratigraphy at Gubbio, Italy. V. Type section for the late CretaceousPaleocene geomagnetic reversal time scale, Geol. Soc. Am. Bull., v. 88, p. 383-389.

Berger, W. H., 1972. Deep sea carbonates: Dissolution facies and age-depth constancy, Nature, v. 236, p. 392-395. , Cenozoic sedimentation in the eastern tropical $\mathrm{Pa}$ cific, Geol. Soc. Am. Bull., v. 84, p. 1941-1954. , 1976. Biogenous deep sea sediments: production, preservation and interpretation. In Riley, J. P. and Chester, R. (Eds.), Chemical oceanography: London (Academic Press), v.5, 2nd ed., p. 265-387.

Berger, W. H. and Health, G. R., 1968. Vertical mixing in pelagic sediments, J. Marine Research, v. 2, no. 2, p. 134-143.

Berger, W. H. and von Rad, U., 1972. Cretaceous and Ceno zoic sediments from the Atlantic Ocean. In Hayes, D. E., Pimm, A. C., et al., Initial Reports of the Deep Sea Drilling Project, v. 14: Washington (U.S. Government Printing Office), p. 787-954.

Berger, W. H. and Winterer, E. L., 1974. Plate stratigraphy and the fluctuating carbonate line, Spec. Publ. Int. Assoc. Sediment., v. 1, p. 11-48.

Bolli, H. M. and Cita, M. B., 1960. Upper Cretaceous and lower Tertiary planktonic foraminifera from the Paderno d'Adda section, northern Italy, XXI Int. Geol. Congress Proc., Norden, Part V, p. 150-161.
Bramlette, M. N., 1965. Massive extinctions in biota at the end of Mesozoic time, Science, v. 148, p. 1696-1699.

Bramlette, M. N. and E. Martini, 1964. The great change in calcareous nannoplankton fossils between Maestrichtian and Danian, Micropaleontology, v. 10, p. 291-322.

Bukry, D., 1974. Phytoplankton stratigraphy, offshore East Africa, Deep Sea Drilling Project, Leg 25. In Simpson, E. S. W., Schlich, R., et al., Initial Reports of the Deep Sea Drilling Project, v. 25: Washington (U.S. Government Printing Office), p. 635-646.

Cande, S. C. and Kristoffersen, Y., 1977. Late Cretaceous magnetic anomalies in the North Atlantic, Earth Planet. Sci. Lett., v. 35, p. 215-224.

Cita, M. B. and Gartner, S., 1971. Deep sea Upper Cretaceous from the western North Atlantic. In Farinacci, A. (Ed.), Second Plankt. Conf. Proc.: Roma, 1970. v. 1, p. 287-319.

Davies, T. A., Luyendyk, B. P., et al., 1974. Initial Reports of the Deep Sea Drilling Project, v. 26: Washington (U.S. Government Printing Office).

Douglas, R. G., 1973. Planktonic foraminifera biostratigraphy in the Central North Pacific Ocean. In Winterer, E. L., Ewing, J. I., et al., Initial Reports of the Deep Sea Drilling Project, v. 17: Washington (U.S. Government Printing Office), p. 673-694.

Fischer, I., 1923. The making of index numbers: Boston (Houghton Mifflin Co.), 2nd ed.

Guinasso, N. L. and Schink, D. R., 1975. Quantitative estimates of biological mixing rates in abyssal sediments, $J$. Geophys. Res., v. 80, p. 3032-3043.

Hay, W. W. and Mohler, H. P., 1967. Calcareous nannoplankton from early Tertiary rocks at Pont-Labau, France and Paleocene-early Eocene Correlations, J. Paleontol., v. 41, p. $1505-1541$.

Heirtzler, J. R., Dickson, G. O., Herron, E. M., Pitman, W. C., III, and LePichon, X., 1968. Marine magnetic anomalies, geomagnetic field reversals and motions of the ocean floor and continents, J. Geophys. Res., v. 73, p. 2119-2136.

Hekel, H., 1973. Nannofossil biostratigraphy, Leg 20, Deep Sea Drilling Project. In Heezen, B. C., MacGregor, I. D., et al., Initial Reports of the Deep Sea Drilling Project, v. 20: Washington (U.S. Government Printing Office), p. 221-248.

Herb, R., 1974. Cretaceous planktonic foraminifera from the eastern Indian Ocean. In Davies, T. A., Luyendyk, B. P., et al., Initial Reports of the Deep Sea Drilling Project, v. 16: Washington (U.S. Government Printing Office), p. 745-769.

Honjo, w., 1976. Coccoliths: production, transportation and sedimentation, Mar. Micropaleontol., v. 1, p. 65-80.

Johnson, B. D., Powell, C. McA., and Veevers, J. J., 1976. Spreading history of the eastern Indian Ocean and Greater India's northward flight from Antarctica and Australia, Geol. Soc. Am. Bull., v. 87, p. 1560-1566.

LeBrecque, J. L., Kent, D. V., and Cande, S. C., 1977. Revised magnetic polarity time scale for Late Cretaceous and Cenozoic time, Geology, v. 5, p. 330-335.

Larson, R. L. and Hilde, T. W., 1975. A revised time scale of magnetic reversals for the Early Cretaceous and Late Jurassic, J. Geophys. Res., v. 80, p. 2586-2594.

Loeblich, A. R., Jr., and Tappan, H., 1957. Correlation of the Gulf and Atlantic Coastal Plain Paleocene and lower Eocene formations by means of planktonic foraminifera, $J$. Paleontol., v. 31, p. 1109-1137. 
Lowrie, W. and Alvarez, W., 1977. Upper Cretaceous-Paleocene magnetic stratigraphy at Gubbio, Italy. III Upper Cretaceous magnetic stratigraphy, Geol. Soc. Am. Bull., v. 88, p. 374-377.

Luterbacher, H. P. and Premoli Silva, I., 1962. Note préliminaire sur une révision du profil de Gubbio, Italie, Riv. Ital. Paleontol., v. 68, p. 253-288.

, 1964, Biostratigrafia del limite Cretaceo-Terziario nell'Appennino Centrale, Riv. Ital. Paleontol. Strat., v. 70. p. 67-129.

Martini, E., 1971. Standard Tertiary and Quaternary calcareous nannoplankton zonation. In Farinacci, A. (Ed.), Second Plankt. Conf. Proc.: Roma 1970, v. 2, p. 739-785.

Matsumoto, T., 1960. Cretaceous-Tertiary boundary in the Japanese Islands, Rept. XXI Internat. Geol. Congress, Norden, Part V, p. 50-56.

Mills, F. C., 1938. Statistical methods: New York (Henry Holt \& Co.).

Perch-Nielsen, K., 1969. Die Coccolithen einiger Dänischer Maastrichtienund Danienlokalitäten, Meddelelser Dansk Geologisk Forening, v. 19, p. 51-68. 1973. Neue Coccolithen aus dem Maastrichtien von Dänemark, Madagaskar und Ägypten, Geol. Soc. Denmark Bull., v. 22, p. 306-333.

Percival, S. F. and Fischer, A. G., 1977. Changes in calcareous nannoplankton in the Cretaceous-Tertiary biotic crisis at Zumaya, Spain. Evol. Theory, v. 2, p. 1-35.

Pimm, A. C., 1974. Sedimentology and history of the northeastern Indian Ocean from Late Cretaceous to Recent. In von der Borch, C. C., Sclater, J. G., et al., Initial Reports of the Deep Sea Drilling Project, v. 22: Washington (U.S. Government Printing Office), p. 717-804.

Pitman, W. C., III, and Talwani, M., 1972. Sea-floor spreading in the North Atlantic, Geol. Soc. Am. Bull., v. 83, p. 619-646.

Premoli Silva, I., 1977. Upper Cretaceous-Paleocene magnetic stratigraphy at Gubbio, Italy. II. Biostratigraphy, Geol. Soc. Am. Bull., v. 88 , p. $371-374$.

Premoli Silva, I. and Luterbacher, H. P., 1966. The Cretaceous-Tertiary boundary in the southern Alps, Riv. Ital. Paleontol. Strat., v. 72, p. 1183-1266.

Raff, A. D., 1966. Boundaries of an area of very long magnetic anomalies in the northeast Pacific, J. Geophys. Res., v. 71, p. 2631-2636.

Roggenthen, W. M. and Napoleone, G., 1977. Upper Cretaceous-Paleocene magnetic stratigraphy at Gubbio, Italy. IV. Upper Maestrichtian-Paleocene magnetic stratigraphy, Geol. Soc. Am. Bull., v. 88, p. 378-382.

Roth, P. H., Mullin, M. M., and Berger, W. H., 1975. Coccolith sedimentation by fecal pellets: laboratory experiments and field observations, Geol. Soc. Am. Bull., v. 86, p. 1079-1084.

Ruddiman, W. F. and Glover, L. K., 1972. Vertical mixing of ice rafted volcanic ash in North Atlantic sediments, Geol. Soc. Am. Bull., v. 83, p. 2817-2836.
Schlich, R., 1974. Sea floor spreading history and deep-sea drilling results in the Madagascar and Mascarene Basins, western Indian Ocean. In Simpson, E. W. S., Schlich, R. et al., Initial Reports of the Deep Sea Drilling Project, v. 25: Washington (U.S. Government Printing Office), p. 663-678.

Sclater, J. G. and Fisher, R. L., 1974. Evolution of the east central Indian Ocean, with emphasis on the tectonic setting of the Ninetyeast Ridge, Geol. Soc. Am. Bull., v. 85, p. 683-702.

Sclater, J. G., Anderson, R. N., and Bell, M. L., 1971. Elevation of ridges and evolution of the central eastern Pacific, J. Geophys. Res., v. 76, p. 7888-7915.

Simpson, E. W. S., Schlich, R., et al., 1974. Initial Reports of the Deep Sea Drilling Project, v. 25: Washington (U.S. Government Printing Office).

Tappan, H., 1968. Primary production, isotopes extinctions and the atmosphere, Paleogeogr., Paleoclimat., Paleoecol., v. 4, p. 187-210.

Thierstein, H. R., 1976. Mesozoic calcareous nannoplankton biostratigraphy of marine sediments, Mar. Micropaleontol., v. 1, p. 325-362.

van Andel, T. H., 1972. Establishing the age of the oceanic crust. Comments on earth sciences, Geophysics, v. 2, p. 157-168.

1975. Mesozoic/Cenozoic calcite compensation depth and the global distribution of calcareous sediments, Earth Planet. Sci. Lett., v. 26, p. 187-194.

van Andel, T. H. and Bukry, D., 1973. Basement ages and basement depths in the Eastern Equatorial Pacific from Deep Sea Drilling Project, Legs 5, 8, 9 and 16, Geol. Soc. Am. Bull., v. 84, p. 2361-2370.

van Hinte, J. E., 1976a. A Cretaceous time scale, Am. Assoc. Petrol. Geol. Bull., v. 60, p. 498-516.

1976b. A Jurassic time scale, Am. Assoc. Petrol. Geol. Bull., v. 60, p. 489-497.

von der Borch, C. C., Sclater, J. G., et al., 1974. Initial Reports of the Deep Sea Drilling Project, v. 22: Washington (U.S. Government Printing Office).

Wilcoxon, J. A., Upper Jurassic-Lower Cretaceous calcareous nannoplankton from the western North Atlantic. In Hollister, C. D., Ewing, J. I., et al., Initial Reports of the Deep Sea Drilling Project, v. 11: Washington (U.S. Government Printing Office), p. 427-458.

Winterer, E. L., 1973, Regional problems. In Winterer, E. L., Ewing, J. I., et al., Initial Reports of the Deep Sea Drilling Project, v. 17: Washington (U.S. Government Printing Office), p. 911-922.

Winterer, E. L., Ewing, J. I., et al., 1973. Initial Reports of the Deep Sea Drilling Project, v. 17: Washington (U.S. Government Printing Office).

Worsley, T.R., 1971. The terminal Cretaceous event, Nature, v. 230 , p. $318-320$.

1974. The Cretaceous-Tertiary boundary event. In Hay, W. W. (Ed.), Studies in paleo-oceanography, Soc. Econ. Paleont. Mineralogists, Spec. Pub. 20, p. 94-125. 